\title{
SELENIUM IN CERTAIN SEDIMENTARY ROCKS
}

\author{
Tapio Koljonen
}

Koljonen, Tapio 1973: Selenium in certain sedimentary rocks. Bull. Geol. Soc. Finland 45, 119-123.

\begin{abstract}
The selenium contents of some sedimentary rocks were studied and tentative averages are presented.

The distribution pattern of selenium in sedimentary rocks can be summarized as follows:

The highest contents are found in clayey sediments (excluding possibly oxidates). Carbonaceous matter clearly has an increasing effect on the amount of selenium present. In slates the geochemistry of selenium partly coincides with that of uranium and vanadium. The organic carbonate sediments contain less selenium than would be expected, that found being is primarily bound by organisms. The organic matter and selenium are probably oxidized by the high calcium content, the selenium migrating out of the sedimentary rock with percolating waters.
\end{abstract}

The rocks formed from sands and evaporites are nearly devoid of selenium.

Tapio Koljonen, Department of Geology and Mineralogy, University of Helsinki, 00170 Helsinki 17, Finland.

\section{Introduction}

This paper, concerning low metamorphic sedimentary rocks, is part of a study of the distribution and geochemical behaviour of selenium in Finnish rocks (Koljonen 1973a; b).

The occurrence of selenium in sedimentary rocks is comparatively well studied in many seleniferous areas where this element is met in toxic concentrations (Beath, Draize, Eppson, Gilbert and McCreary 1934; Beath, Gilbert and Eppson 1937; Beath, Hagner and Gilbert 1946; Fleming and Walsh 1957; Walsh, Fleming, O'Conner and Sweeney 1951; Williams and
Byers 1936; Williams, Lakin and Byers 1941). The behaviour of selenium in sedimentary rocks is covered by a considerable amount of literature, the most comprehensive reviews having been published by Trelease and Beath (1949), and Rosenfeld and Beath (1964).

The information dealing with the abundance of selenium in common sedimentary rocks outside the seleniferous area is scanty. Minami (1936) published some determinations of Japanese and European slates and Sindeeva (1964) made three analyses of the shales of Estonian SSR. For comparison with the data presented in this paper, their values are reproduced here (Table 1 ). 
TABLE 1

The selenium analyses presented by Minami (1936) and Sindeeva (1964).

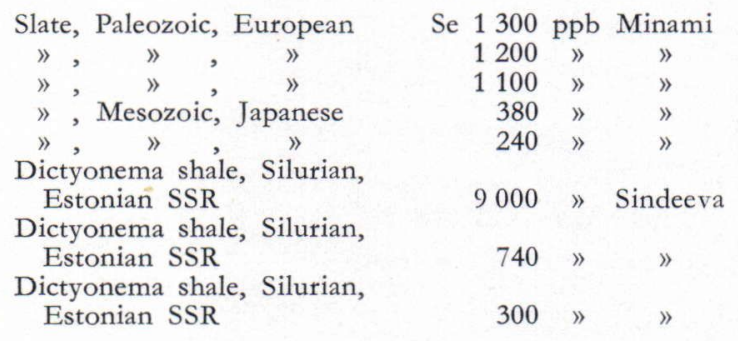

According to Goldschmidt and Strock (1935) the selenium content of an average of 32 German limestones is less than $100 \mathrm{ppb}$. For comparison, some averages presented in previous literature are reviewed. However, as stated by Turekian and Wedepohl (1961) the values are significant only in order of magnitude.

\section{TABLE 2}

The average selenium contents presented by Green (1959), Turekian and Wedepohl (1961) and Vinogradov (1962).

\begin{tabular}{|c|c|c|c|c|}
\hline Shale & 600 & $\mathrm{ppb}$ & Green & \\
\hline Slate & 600 & \# & Turekian and & Wedepohl \\
\hline Sandstone & 50 & » & $»$ & $»$ \\
\hline Carbonate & $?-100$ & $»$ & Green & \\
\hline Carbonate & 80 & $\gg$ & Turekian and & Wedepohl \\
\hline Slate and Clay & 600 & " & Vinogradov & \\
\hline
\end{tabular}

Finland is part of an old Precambrian shield and only a few occurrences of younger sedimentary rocks are known. Therefore, for comparison, a part of the samples were taken from outside Fennoscandia.

In the following, the selenium contents of various sedimentary rock groups are briefly reviewed and compared with the known behaviour of selenium in sedimentary rocks.

\section{Sandstones}

Table 3, Nos. 1-2. The samples analysed have originally been sands containing quartz and feldspars and only sparsely clayey material. Selenium tends to follow femic minerals and sulphides (Koljonen 1973, 12-13). These minerals are most easily disintegrated by mechanical and chemical weathering.

The detected selenium content is low, normally under $10 \mathrm{ppb}$, this being under the lower analytical limit of the method used.

\section{Shales}

Table 3, Nos. 3-6. The studied samples are metamorphosed sediments which originally contained much clay and probably organic residue, but little quartz and feldspars. During exogenic processes selenium is easily oxidized to an elemental form and is adsorbed into clays. It is, therefore, considerably enriched into sedimentary rocks of clayey origin. This pehomenon has been observed in the seleniferous areas of sedimentary rock in which the content of selenium is higher in the shales than in the adjacent layers of sandstones or limestones (Byers 1937; Fleming and Walsh 1957). When the carbon content is high, as in the studied bituminous shale which contains uranium (Table 3, No. 4), the selenium content is also high (Table 3, No. 3, contains about $200 \mathrm{ppm} \mathrm{U).} \mathrm{Selenium}$ tends to follow uranium and in places vanadium in exogenic processes. This phenomenon has been observed in many sedimentary rocks especially in the USA (Beath and Gilbert 1936; Beath, Hagner and Gilbert 1946; Cannon 1952, 1953, 1954, 1956, 1957; Cannon and Kleinhampl 1956; Cannon and Starrett 1956; Coleman 1956; Coleman and Delevaux 1957; Granger, Santos Dean and Moore 1961; Grutt 1956; Keys and White 1956; Love 1954; Miesch and Connor 1956; Vine and Prichard 1954).

\section{Limestones}

Table 3, Nos. 7-12. The selenium content is low in limestones. This is in accordance with the known chemical behaviour of selenium, according to which selenium easily migrates if 
TABLE 3

Selenium contents of the sedimentary rocks

\begin{tabular}{|c|c|c|}
\hline No. & Rock and locality & $\begin{array}{c}\text { Selenium } \\
\text { content } \\
\text { ppb }\end{array}$ \\
\hline 1 & $\begin{array}{l}\text { Sandstone. Eura, Kiperjärvi, Finland (Sederholm 1903; and 1913, 112-114; Laitakari 1925, 1-43; } \\
\text { Simonen and Kouvo 1955, 57-58) }\end{array}$ & $<1$ \\
\hline 2 & 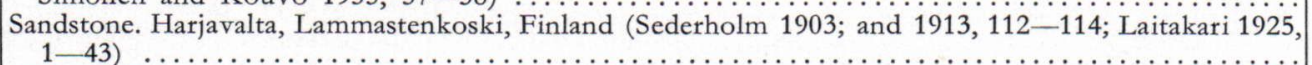 & \\
\hline 3 & 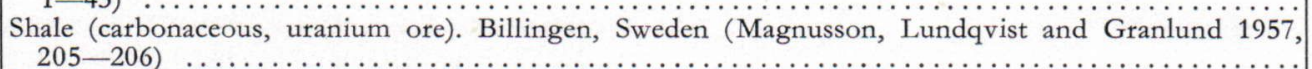 & 1220 \\
\hline 4 & Shale (bituminous). Kohtla, Virumaa, Estonia SSR ............ & 410 \\
\hline 5 & Siltstone. Muhos, Monta, Finland (Brenner 1941; Lokka 1950; Tynni and Siivola 1966) & 230 \\
\hline 6 & Shale. Hungary $\ldots \ldots \ldots \ldots \ldots$ & 140 \\
\hline 7 & $\begin{array}{l}\text { Limestone (fossiliferous). Jomala, Finland (Asklund and Kulling 1926, 509_511; Kulling 1926, 503-509 } \\
\text { Metzger } 1922,1-8 \text {; and } 1927,1-20) \ldots \ldots \ldots \ldots \ldots \ldots \ldots \ldots \ldots \ldots \ldots \ldots \ldots \ldots \ldots \ldots \ldots \ldots \ldots \ldots \ldots \ldots \ldots \ldots\end{array}$ & \\
\hline 8 & Limestone (mollusca). Estonia SSR ..... & 30 \\
\hline 9 & $\begin{array}{l}\text { Limestone (the baltic limestone, fossiliferous). Mariehamn, Ytternäs, Sökskär, Finland (Asklund and } \\
\text { Kulling 1926, 509-511; Kulling 1926, 503-509; Metzger 1922, 1-8; and 1927, 1-20) ....... }\end{array}$ & 30 \\
\hline 10 & $\begin{array}{l}\text { Limestone (fossiliferous). Jomala, Ytterby, Finland (Asklund and Kulling 1926, 509_511; Kulling 1926, } \\
502-509 \text {; Metzger 1922, } 1-8 \text {; and } 1927,1-20) \ldots \ldots \ldots \ldots \ldots \ldots \ldots \ldots \ldots \ldots \ldots \ldots \ldots \ldots \ldots \ldots \ldots \ldots \ldots \ldots \ldots \ldots \ldots \ldots \ldots \ldots\end{array}$ & 0 \\
\hline 11 & Limestone (coral). Kalinin, USSR . & 20 \\
\hline 12 & Limestone (fossiliferous). Sala, Västmanland, Sweden & $<10$ \\
\hline $13 \mid$ & |Halite ( $\mathrm{NaCl}$ ). Lehrte, W. Germany (Goldschmidt and Hefter 1933) & $<10$ \\
\hline
\end{tabular}

oxidized. The sediments containing carbonates are neutral or only slightly acidic. The organic compounds, which may have enriched selenium, are disintegrated and oxidized. Selenium is freed in the oxidized form and migrates with solutions. Beath, Gilbert and Eppson (1937) and Chenzov (1961) have observed that in some places selenium occurs in carbonaceous beds, but not in carbonate beds in the same formation.

\section{Evaporate}

One sample, halite (Table 3, No. 13), is analysed. The result is in accordance with that obtained by Goldschmidt and Hefter (1933, 250252). The content of selenium in evaporates is very low and far below the average in common sedimentary rocks.

\section{Summary}

The average selenium contents in sedimentary rocks are presented only in order of magnitude representing contents typical to the investigated rocks and areas.

The results in this study are well in accordance with the previous studies presented in Table 1 and Table 2.

Tentative averages calculated from Table 3.

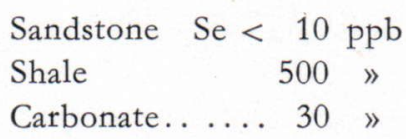

Acknowledgements - See: Koljonen Tapio (1973) Selenium in certain metamorphic rocks. Bull. Geol. Soc. Finland 45, 111. 


\section{REFERENCES}

Asklund, B. and Kulling, O. (1926) New data on the geology of the Aland-Archipel. Geol. För. Stockh. Förh. 48, 509-511.

Beath, O. A., Draize, J. H., Eppson, H. F., Gilbert, C. S. and McCreary, O. C. (1934) Certain poisonous plants of Wyoming activated by selenium and their association with respect to soil types. Am. Pharm. Assoc. J. 23, 94-97.

Beath, O. A. and Gilbert, C. S. (1936) Selenium-bearing vegetation during late Cretaceous time. Science 84, No. 2187, 484-485.

Beath, O. A., Gilbert, C. S. and Eppson, H. F. (1937) Selenium in soils and vegetation associated with rocks of Permian and Triassic age. Am. J. Bot. 24, 96-101.

Beath, O. A., Hagner, A. F. and Gilbert, C. S. (1946) Some rocks and soils of high selenium content. Wyo. Geol. Surv. Bull. 36.

Brenner, Th. (1941) Ein ungewöhnliches Kalkschlammsteinsediment von Muhos in Mittelfinnland. Geol. Rundsch. 32, 535- 549 .

Byers, H. G. (1937) The origin, distribution, and effects of selenium. Soil Sci. Soc. Am., Proc. 1, 327.

Cannon, H. L. (1952) The effect of uranium-vanadium deposits on the vegetation of the Colorado Plateau. Am. J. Sci. 250, 735-770.

- (1953) Geobotanical reconnaissance near Grants, N. Mex. U. S. Geol. Surv., Circ. 264.

- (1954) Botanical methods of prospecting for uranium. Am. Inst. Min. Metall. Eng., Trans. 199, 217-220.

- (1956) Advances in botanical methods of prospecting for uranium. Int. Geol. Congr., 20th, Mex. 1956, Resumenes Trab. Presentados, 359-360.

- (1957) Description of indicator plants and methods of botanical prospecting for uranium deposits on the Colorado Plateau. U. S. Geol. Surv., Bull. 1030-M, 399-516.

— and Kleinhampl F. J. (1956) Botanical methods of prospecting for uranium. U. S. Geol. Surv., Prof. Pap. $300,681-686$.

- and Starrett, W. H. (1956) Botanical prospecting for uranium on La Ventana Mesa, Sandoval County, New Mexico. U. S. Geol. Surv., Bull. 1009-M, 391407.

Chentzov, I. G. (1961) Selenium in Paleogene deposits of Central Asia. Geochem. Cosmochim. Acta 23, 152.

Coleman, R. G. (1956) The occurrence of selenium in sulfides from sedimentary rocks of the western United States (abstr.). Econ. Geol. 51, 112.

- and Delevaux, M. (1957) Occurrence of selenium in sulfides from some sedimentary rocks of the western United States. Econ. Geol. 52, 499-527.
Fleming, G. A. and Walsh, T. (1957) Selenium occurrence in certain Irish soils and its toxic effects on animals. R. Ir. Acad. Proc. 58, Sec. B, 151-166.

Goldschmidt, V. M. and Hefter, O. (1933) Zur Geochemie des Selens. Nachr. Ges. Wiss. Göttingen, Math.-Phys. Kl. IV, 36, 245-252.

Goldschmidt, V. M. and Strock, L. W. (1935) Zur Geochemie des Selens II. Nachr. Ges. Wiss. Göttingen, Math.-Phys. Kl. IV, N.F. 1, 123-142.

Granger, H. C., Santos, E. S., Dean, B. G. and Moore, F. B. (1961) Sandstone-type uranium deposits at Ambrosia Lake New Mexico. Econ. Geol. 56, 11791209.

Green, J. (1959) Geochemical table of the elements for 1959. Bull. Geol. Soc. Am. 70, 1127-1183.

Grutr, E. W., Jr. (1956) Uranium deposits in Tertiary sedimentary rocks in Wyoming and northern Colorado. U. S. Geol. Surv., Prof. Pap. 300, 361-370.

Keys, W. S. and White, R. L. (1956) Investigation of the Temple Mountain collapse and associated features, San Rafael Swell, Emery County, Utah. U. S. Geol. Surv., Prof. Pap. 300, 285-298.

Koljonen, T. (1973a) Determination of selenium in rocks, soils, and plants. Suom. Kemistl. B 46, 133 138.

- (1973b) Selenium in certain igneous rocks. Bull. Geol. Soc. Finl. 45, 9-22.

Kulling, O. (1926) Nya data till Ålands geologi II. Den nyupptäckta östersjökalken i Lumparfjärden. Geol. För. Stockh. Förh. 48, 503-509.

LAItAkari, A. (1925) Über das jotnische Gebiet von Satakunta. Bull. Comm. géol. Finl. 73.

LокKA, L. (1950) Chemical analyses of Finnish rocks. Bull. Comm. géol. Finl. 151.

Love, J. D. (1954) Preliminary report on uranium in the Gas Hills area, Fremont and Natrona Counties, Wyoming. U. S. Geol. Surv., Circ. 352.

Magnusson, N. H., Lundqvist, G. and Granlund, E. (1957) Sveriges Geologi (3. Ed.). Scandinavian University Books, Stockholm.

Metzger, A. A. Th. (1922) Beiträge zur Paläontologie des nordbaltischen Silurs im Ålandsgebiet. Bull. Comm. géol. Finl. 56.

- (1927) Zur Kenntnis des nordbaltischen KambroSilurs auf Åland und im südwestlichen Küstengebiet Finnlands. Fennia 47: 12.

Mresch, A. T. and Connor, J. J. (1956) Distribution of elements. (In: Geologic investigations of radioactive deposits) Semiannu. prog. report, Dec. 1, 1955, to May 31, 1956. U. S. Surv. TEI-620, issued by U. S. At. Energy Comm., Tech. Inf. Serv., Oak Ridge, Tenn., $128-146$. 
Minani, E. (1935) Selen-Gehalte von europäischen und japanischen Tonschiefern. Nachr. Ges. Wiss. Göttingen, Math.-Phys. K1. IV, N.F. 1, 143-145.

Rosenfeld, I. and Beath, O. A. (1964) Selenium. Geobotany, biochemistry, toxicity and nutrition. Academic Press, New York.

Sederholm, J. J. (1903) General geological map of Finland, 1: 400 000, Sheet B2, Tampere. Geologinen tutkimuslaitos, Otaniemi.

- (1913) Vuorilajikartan selitys B2, Tampere. General geological map of Finland, 1: 400000 . Geologinen tutkimuslaitos, Otaniemi.

Simonen, A. and Kouvo, O. (1955) Sandstones in Finland. Bull. Comm. géol. Finl. 168, 57-88.

Sindeeva, N. D. (1964) Mineralogy and types of deposits of selenium and tellurium. Interscience Publishers, New York-London-Sydney.

Trelease, S. F. and Beath, O. A. (1949) Selenium, its geological occurrence and its biological effects in relation to botany, chemistry, agriculture, nutrition and medicine. Published by the authors, New York.

Turekian, K. K. and Wedepohl, K. H. (1961) Distri- bution of the elements in some major units of the Earth's crust. Bull. Geol. Soc. Am. 72, 175-192.

Tynni, R. and Sirvola, J. (1966) On the Precambrian microfossil flora in the siltstone of Muhos, Finland. Bull. Comm. géol. Finl. 222, 127-133.

Vine, J. D. and Prichard, G. E. (1954) Uranium in the Poison Basin area, Carbon County, Wyoming. U. S. Geol. Surv., Circ. 344.

Vinogradov, A. P. (1962) Average contents of chemical elements in the principal types of igneous rocks of the earth's crust. Geochemistry 7, 641-664.

Walsh, T., Fleming, G. A., O'Connor, R. and Sweeney, A. (1951) Selenium toxicity associated with an Irish soil series. Nature 168, 881.

Williams, K. T. and Byers, H. G. (1936) Selenium compounds in soils. Ind. Eng. Chem., Ind. Ed., 28, $912-$ 914.

Williams, K. T., Lakin, H. W. and Byers, H. G. (1941) Selenium occurrence in certain soils in the United States, with a discussion of related topics; Fift report. U. S. Dep. Agric., Tech. Bull. 758.

Manuscript received, November 17, 1972. 